\title{
Vasúti fejlesztések utasszemmel
}

\begin{abstract}
A vasúti beruházások, fejlesztések rendkívüil idő- és pénzigényes munkák, amelyek előkészítése és megvalósítása mindig kiváltja az utazóközönség érdeklődését. A most közreadott írás érdekessége, hogy egy olyan vasúti szakember összegezte tapasztalatait, aki a korábbi szakmai életében széles körü ismeretekre tett szert, és ezt kiegészítette a jelenleg vasúton sokat utazó "átlag-utas" megfigyeléseivel. Értelemszerűen az „átlag-utasnak” nem áll rendelkezésre a teljes körü adatbázis, de a nyilvánosan hozzáférhetö anyagok, táblázatok összevetése a konkrét megfigyelésekkel és tapasztalatokkal sokat segíthetnek, hogy a jelzett hibákhoz hasonlók a jövőben ne forduljanak elö, és a szerényen megfogalmazott javaslatokat a gyakorlati megvalósítás során figyelembe vegyék.
\end{abstract}

DOI 10.24228/KTSZ.2017.3.3

\section{Perger Imre}

Nyugalmazott MÁV igazgató

e-mail: pergeri@t-online.hu

\section{BEVEZETÉS}

A 2007-2013 közötti európai uniós költségvetési időszakban 540 kilométer vasúti pályát, 73 állomást, illetve megállóhelyet korszerüsítettek, létesítettek, és elkészült $40 \mathrm{db}$ közúti alul- és felüljáró, $42 \mathrm{db}$ gyalogos felüljáró és $60 \mathrm{db}$ peron. Emellett 173 ezer négyzetméter zajvédőfalat és $6100 \mathrm{db} \mathrm{P}+\mathrm{R}$ parkolóhelyet létesített a MÁV Zrt.

Ezek rendkívül szép eredmények, de mit érzékel mindebből az, aki a magyar vasút szolgáltatatásait naponta vagy csak esetlegesen veszi igénybe?

A magyar vasutat az elmúlt évtizedekben rengeteg kritika érte, mert a közvélemény szemében pénznyelö, megbízhatatlan, korszerütlen, lassú, leépült, drága, elmaradott, a dolgozói pedig primitívek, udvariatlanok.

Az alábbiakban kiragadott példák alapján szubjektív helyzetjelentést kívánok adni arról, hogyan láthatja egy vasúton sokat utazó személy, - aki ma már elsősorban utasszemmel figyeli a MÁV vasúti közlekedését - az elmúlt évek fejlesztéseinek hatását, eredményeit és eredménytelenségeit.

\section{EGY KIS TO̊RTÉNELMI VISSZATE- KINTÉS}

Összehasonlításként érdemes utalni arra, hogy 1970 és 1980 között 11 év alatt 3050 km vasúti felépítményt cseréltek ki, és $815 \mathrm{~km}$ vonalat villamosítottak. (Ezen időszak adatai által a szerzö rendelkezésére. A föszerk.) A 30 évenként esedékes pályarekonstrukció a hét év alatt a MÁV fôvonalain $7 \times 200=1400 \mathrm{~km}$ felúiítást igényelt volna, mivel $6000 \mathrm{~km} / 30$ év $=200 \mathrm{~km} / \mathrm{é}$ a folyamatos szinten tartás szükséglete! Ugyanakkor a mellékvonalak és állomási vágányok rendbetétele is legalább évi 100-150 km (hét év alatt 700$1050 \mathrm{~km}$ ) felújítást igényelne.

A GYSEV 2010-ben 56, 2015-ben 87, 2016-ban $49 \mathrm{~km}$, összesen $192 \mathrm{~km}$ vasútvonalat villamosított, és egyidejűleg a szükséges felújítást, korszerüsítést is elvégezte. Ezen felül a központi forgalomirányítási rendszert is kiépítették. 


\section{Vasúti közlekedés}

\begin{tabular}{|c|c|c|}
\hline & vonalfelújítás & $\begin{array}{l}\text { vonalvillamo- } \\
\text { sítás }\end{array}$ \\
\hline 1970 & 257 & 159 \\
\hline 1971 & 226 & 82 \\
\hline 1972 & 155 & 4 \\
\hline 1973 & 203 & 92 \\
\hline 1974 & 271 & 115 \\
\hline 1975 & 217 & 68 \\
\hline 1976 & 342 & 5 \\
\hline 1977 & 347 & 6 \\
\hline 1978 & 345 & 66 \\
\hline 1979 & 355 & 104 \\
\hline 1980 & 332 & 114 \\
\hline
\end{tabular}

1970 és 1980 között a MÁV 834 db új mozdonyt, $180 \mathrm{db}$ motorvonatot és $1768 \mathrm{db}$ személykocsit szerzett be. Ugyanakkor 2007-2013 között a MÁV új eszközként $25 \mathrm{db}$ villamos mozdonyt, $123 \mathrm{db}$ villamos motorvonatot és a $2 \mathrm{db}$ IC+ kocsit vásárolt.

\begin{tabular}{|c|c|c|c|c|}
\hline & $\begin{array}{l}\text { villamos } \\
\text { mozdony }\end{array}$ & $\begin{array}{l}\text { dízel } \\
\text { moz- } \\
\text { dony }\end{array}$ & $\begin{array}{l}\text { motorvo- } \\
\text { nat és mo- } \\
\text { torkocsi }\end{array}$ & $\begin{array}{c}\text { személy- } \\
\text { kocsi }\end{array}$ \\
\hline 1970 & 24 & 44 & 8 & 233 \\
\hline 1971 & 27 & 0 & 11 & 223 \\
\hline 1972 & 22 & 96 & 11 & 139 \\
\hline 1973 & 22 & 59 & 0 & 53 \\
\hline 1974 & 19 & 99 & 0 & 105 \\
\hline 1975 & 23 & 90 & 10 & 117 \\
\hline 1976 & 31 & 30 & 0 & 109 \\
\hline 1977 & 10 & 15 & 0 & 64 \\
\hline 1978 & 15 & 24 & 2 & 84 \\
\hline 1979 & 0 & 154 & 38 & 254 \\
\hline 1980 & 20 & 10 & 100 & 388 \\
\hline $\begin{array}{l}11 \text { év } \\
\text { alatt }\end{array}$ & 213 & 621 & 180 & 1769 \\
\hline
\end{tabular}

\section{VILLAMOS MOTORVONATOK BE- SZERZÉSE}

\subsection{Az igazi sikertörténet a FLIRT mo- torvonatok beszerzése}

Az elmúlt időszak legsikeresebb vasúti beruházásának a villamos motorvonatok beszerzését minő- síthetjük. A négy projektben beszerzett, összesen $123 \mathrm{db}$ STADLER FLIRT szerelvénnyel megúiították az elővárosi személyszállítást. Annak ellenére, hogy az új szerelvények ülőhelyszáma csak 325 Bhv kocsinak felel meg, a nagyobb futásteljesítményük miatt ennél lényegesen nagyobb szerephez jutottak. Bár nem oda valók, a motorvonatok a távolsági közlekedést is attraktívabbá tették, ha ilyen fordulóba osztották be azokat Győr, a Balaton, Nyíregyháza vagy Eger és a főváros között.

A vonatok megbízhatósága, kényelme igazi vonzerőnek bizonyult. Az egységes, egymással kompatibilis, jól karbantartott szerelvények európai színvonalú kiszolgálást nyújtanak.

\subsection{A nagy befogadóképességúi motorvo- natok beszerzése}

A budapesti elővárosi közlekedés legnagyobb forgalmú vonalainak csúcsforgalmi vonataira a beszerzett 211 ülöhelyes vonatok kapacitása elégtelen, ezért tendert írtak ki 30 darab nagy befogadóképességü, 300-600 személyes villamos motorvonat beszerzésére.

3. táblázat: A budapesti elövárosi vonalak
vonatonkénti utasszáma 2010 [3]
\begin{tabular}{|c|c|c|c|c|}
\hline vonal & \multicolumn{3}{|c|}{ vonat db az utasfó kategóriában } \\
\hline & $\begin{array}{c}1-250 \\
\text { utas }\end{array}$ & $\begin{array}{c}250-400 \\
\text { utas }\end{array}$ & 400 - utas & Együtt \\
\hline 1 & 42 & 6 & 2 & 50 \\
\hline 2 & 46 & 8 & 1 & 55 \\
\hline $30 a$ & 89 & 13 & & 102 \\
\hline $40 a$ & 54 & 10 & 1 & 65 \\
\hline 70 & 81 & 28 & 10 & 119 \\
\hline 71 & 45 & 7 & & 52 \\
\hline 80 & 65 & 7 & 2 & 74 \\
\hline $100 a$ & 92 & 9 & 16 & 117 \\
\hline $120 a$ & 91 & 13 & 11 & 115 \\
\hline 142 & 31 & 1 & & 32 \\
\hline 150 & 47 & 3 & & 50 \\
\hline $\begin{array}{c}\text { Összes } \\
\text { vonat }\end{array}$ & 683 & 105 & 43 & 831 \\
\hline $\begin{array}{c}\text { megoszlás } \\
\%\end{array}$ & 82,19 & 12,64 & 5,17 & 100 \\
\hline & & & & \\
\hline
\end{tabular}

A 3. táblázatból látható, hogy a 400 db ülöhelynél nagyobb befogadóképességü vonatok megfelelő kihasználtsága nem biztosítható, mivel a budapesti elővárosi forgalomban na- 
ponta legfeljebb 43 olyan (csúcsidei) vonat van, ahol 400-nál több utas várható. Így felesleges kapacitások mozgatása lesz napközben vagy takarékossági okokból - csökkentik a vonatkínálatot.

\subsection{További motorvonatok beszerzése}

A tervezett beszerzésen felül a jelenlegi menetrendi kínálatban hálózati szinten mintegy 50 darab 60-130 ülőhelyes villamos motorvonatra lenne szükség, amelyekkel kiválthatók lennének az 1-3 kocsis, mozdony vontatású szerelvények vagy a felsővezeték alatt közlekedő Bz motorvonatok. Jelenleg 40-50 darab V43 sorozatú mozdony közlekedik 1-3 db kocsit továbbítva.

További vonalvillamosítási projektek indulnak (Mezőzombor-Sátoraljaújhely, Püspökladány-Biharkeresztes, ZalaszentivánNagykanizsa, stb.), tehát a kisebb villamos motorvonatok beszerzésének előkészítése azonnali feladat. Már most gondolni kellene az észak-balatoni villamosítás jármüigényére, a csatolva közlekedtethető villamos és dízel motorvonatok beszerzésével.

Új villamos motorvonatok beszerzésére a továbbiakban is szükség lesz. A vasút és az állam mozgásterét nagymértékben növelni lehetne az olyan tenderkiírásokkal, amelyekben - a megfelelő forrás rendelkezésre állása esetén opcionálisan a járműcsalád különböző befogadóképességű szerelvényei (esetleg kompatibilis dízel motorvonatok) is lehívhatók lennének.

Az uniós támogatások legrugalmasabb területe a jármübeszerzés, amellyel a maradék források azonnal felhasználhatók, ha nincs szükség új tenderezési eljárásra. Ezt a módszert sikerrel alkalmazták már a balti államok és a BKK is a jármübeszerzéseik során.

\section{A KÖZELMÚLT FONTOSABB VO- NALFEJLESZTÉSEI}

\subsection{Az állatorvosi ló: Budapest-Esztergom}

A Budapest-Esztergom vasútvonal 1893-1895 között épült meg, míg a felújítása, korszerüsítése lassan 10 éve folyik, de a beruházás be- fejezésének végső dátuma a messze jövőben lebeg. A felújítás kezdeti lépése viszonylag frappáns volt, mert az elavult, alacsony sebességü újpesti vasúti híd teljes hídzára csak három hónapig tartott 2008. 06. 21.-2008. 09. 21 között. Ez idő alatt a vonatok a Margit híd budai hídfőjéig, illetve Kaszásdűlőig jártak, megvalósítva az igazi interoperábilis szolgáltatást, a vasúti rendszerek közötti teljes átjárhatóságot. Ez tekinthető a 21. századi magyarországi vasút-villamos (tram-train) sikeres próbajáratának, amit azóta elfelejtettek. A zömmel a nyári iskolaszünetre eső kényelmetlenséget az utasok viszonylag jól viselték, és a HÉV vonalon nagyobb zavarok nélkül lebonyolódott a forgalom. Sokan igényelték volna azonban a közvetlen budai kapcsolat további fenntartását. A hídzárhoz sajnos nem kapcsolódtak a személyforgalomból kizárt pesti oldalon a vasúti közlekedés gyorsítását vagy biztonságát javító felújítási munkálatok, ezeknek még hosszú ideig szenvedni fogjuk a hatásait.

A következő felújítási ütem 2012 májusában kezdődött és 2015 augusztusáig a vasúti forgalom szünetelt. Az építési munkák az eredetileg tervezett időtartam kétszereséig tartottak, és a beruházás második üteme lekörözte az elsőt, mivel a gyorsabban felújított Pilisvörösvár-Esztergom vonalszakaszon a vasúti közlekedés már 2013 decemberében megindulhatott. Ugyanakkor a nagyobb forgalmú, Budapesthez közelebbi vonalrészen maradt a vonatpótló közlekedés. Az utasok megpróbáltatásait tetézte a 10 -es föút zsúfoltsága és műszaki állapota miatti többletmenetidő szükséglet.

A vasúti beruházás keretében megújult Solymár, Pilisvörösvár és Piliscsaba állomásépülete, öt új megállóhely (Aquincum, Aranyvölgy, Szélhegy, Vörösvárbánya, Magdolnavölgy) és egy két kilométer hoszszú forgalmi kitérő (Örhegy) létesült. B+R és $\mathrm{P}+\mathrm{R}$ parkolók épültek, korszerü peronok és utastájékoztató berendezések épültek. Autóbusz-fordulók, közúti alul- és felüljárók épültek és a vasútépítéshez kapcsolódóan kissé megkésve - Aquincum HÉV megállót is áthelyezték. Új párhuzamos közút és felül- 


\section{Vasúti közlekedés}

járó épült a Bécsi út és az Üröm felé vezető közúti kapcsolatnál kiépített körforgalomig, valamint teljesen új közút épült (felüljáróval) a 10-es foúttól Solymárig.

A megnyúlt kivitelezési idő alkalmat adott arra, hogy a tervezett villamosítás előmunkálataiként a felsővezeték-tartó oszlopok egy részét a pályaépítéssel párhuzamosan beépíthessék. 2016 őszén hétvégi és éjszakai vágányzárakban megkezdődött a vonal villamosítása. Jelenleg az „átadott” vasútvonalon folyamatban vannak a következő munkák:

- a villamos felsővezetéki rendszer kiépítése, amelyhez bővíteni kell az istvántelki villamos alállomást és újat kell építeni Dorogon. A villamos vontatás felvételéhez elengedhetetlen a biztosítóberendezések elkészülte is,

- Angyalföld és Újpest között új, második vágány épül (a kitérője már az alapütemben beépült). Angyalföld állomáson széles utasperonokat, lépcsőket alakítanak ki, gyalogos aluljárót építenek a Béke úthoz, átszállási kapcsolattal a villamoshoz, és korszerüsítik a vágányhálózatot. Újpest megállóhelyen két lift telepítésével biztosítják az akadálymentes közlekedést a metró és a vasúti peronok között, valamint korszerű magasperon, perontető és zajvédő fal épül,

- a Rákosrendezö-Angyalföld vonalszakasz új nyomvonalra helyezése, továbbá a Balzsam utca korrekciója és az Újpalotai úti útátjáró átépítése,

- Dorog és Klotildliget felvételi épülete átépül. Dorogon épül az új, második vágány a mészkőhegyi elágazásig. (Kérdés, hogy a végpont felőli oldalon miért nem épül ki hasonló módon a II. vágány a tokodi elágazásig?) Dorogon autóbusz-forduló és összekötő út épül az esztergomi 111-es fóthoz. Esztergomban folyik az állomás vágányhálózatának átépítése, a felvételi épület és az állomás előtti tér felújítása és az új biztosítóberendezési üzemi épület kivitelezése. Tizenkét kocsiállásos autóbuszállomás és VOLÁN forgalmi épület készül, továbbá a vasútállomás közelében két körforgalom és három jelzőlámpás csomópont is épül,
- Magdolnavölgy megállóhelyen építik a peronhoz vezető járdát, hogy a lakott helyről elérhető legyen a vasút.

A vasútvonal zavartalan vonatforgalmának biztosításához és a tervezett vonatmenynyiség közlekedtetéséhez elengedhetetlenül szükség lenne Rákosrendező állomás és a Rákosrendező-Budapest-Nyugati vonalszakasz felújítására, kapacitásbővítésére. Ennek várható időpontjáról és a kivitelezés időtartamáról jelenleg elképzelések nem ismertek. Így az esztergomi vonalra tervezett vonatszám-bővítés sorsa bizonytalan, mert a Nyugatiba óránként csak 2 pár vonat közlekedhet. Emiatt évekig provizórikus és félmegoldásokban kell majd gondolkodni. Ha Rákosrendező és Nyugati pu. korszerűsítésére sor kerül, az újabb évekre ellehetetleníti az esztergomi vonal Belvárosba irányuló személyforgalmát. Ennek részbeni feloldását biztosíthatná a Körvasút ismételt bekapcsolása a vasúti személyszállításba, amelynek lehetőségét a Közlekedéstudományi Szemle 2016. 3. számában megjelent cikk vizsgálta [2].

Ami a vonalon eddig megépült, az többé-kevésbé müködik.

Szép a három felújított állomásépület, jók és többségükben kihasználtak a $\mathrm{P}+\mathrm{R}$ és $\mathrm{B}+\mathrm{R}$ parkolók. A kezdeti bizonytalanság után a várótermek nyitva tartása is megoldódott. Jó a vonalra kidolgozott írásos utastájékoztató rendszer, bár elhelyezésük és frissítésük nem mindig megoldott.

Sok ugyanakkor az elfogadhatatlan kivitelezési hiba, a szakszerütlenség. A peronok tele vannak kábelaknákkal, barbár módon oldották meg a fémberendezések földelését, vízelvezetési gondok vannak, a peronkövezés sok helyen egyenetlen.

Nem egyértelműek a megközelítési útvonalak. Több helyen beépített akadályokkal nehezített az eljutás, rossz helyen vannak az infooszlopok, és nem takarítják rendszeresen az üvegfelületüket. A felsővezeték-tartó és világítási oszlopok elhelyezése esetleges. 


\section{Vasúti közlekedés}

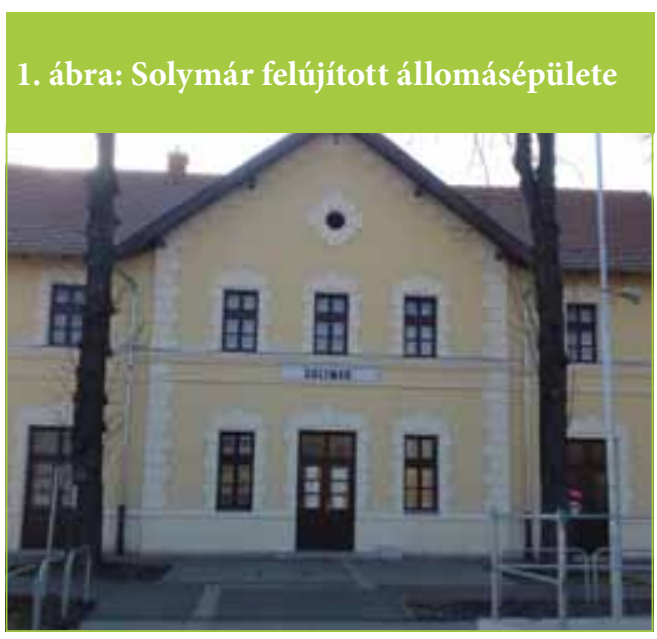

Ami teljesen elrontott, az Aquincum megállóhely, mint „intermodális csomópont”. A megállóhelyet eleve a Szentendrei út fölé kellett volna telepíteni, közvetlen lejutással mindkét vasúti peronról a fóútvonal mindkét oldalához és mindkét HÉV peronhoz. Az utólag a BKK projektjében megépített új gyalogos híd csak az egyik oldal megközelítését teszi lehetővé. Emiatt utasok csoportjai másznak át a peronvégen az egyik oldalról a másikra. Ez elfogadhatatlan.

Mivel a Szentendrei út feletti híd mindkét oldalán van szolgálati járda és a Duna felöli hídfő mindkét oldalán épült keskeny szolgálati lejáró, amelyet az utasok nem használhatnak, néhány millió forintból tisztességes

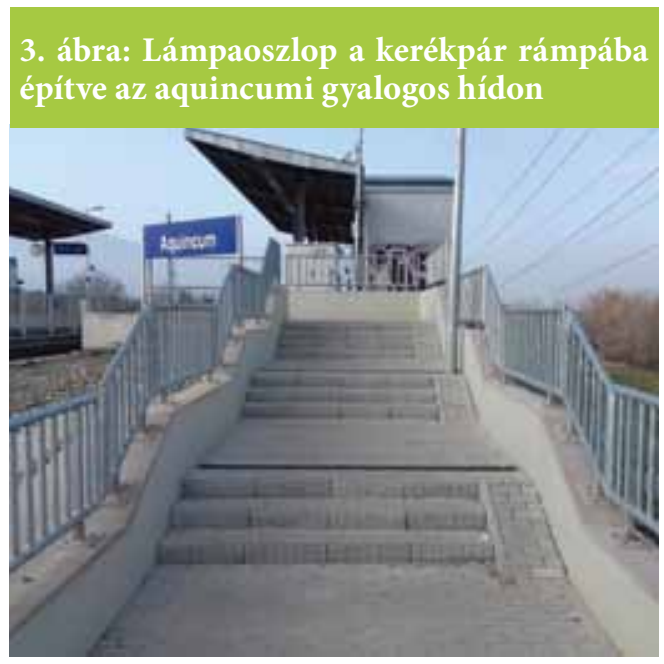

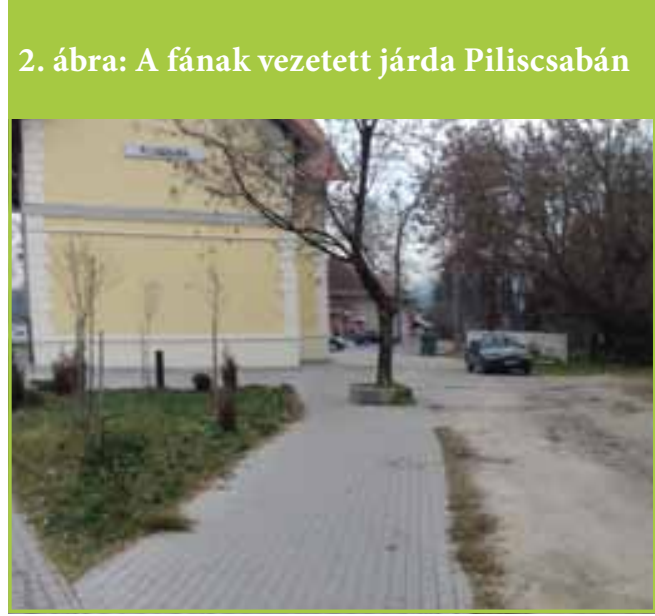

megoldást lehetne nyújtani a jelenleg használt szolgálati útvonalak közforgalmasításával és a peronvégek közötti átjárás biztosításával.

A BKK HÉV és buszmegállójának kialakítása (egymástól való elválasztása, a különböző közlekedési terültek között elhelyezett oszlopok „erdeje”, az utólag épített gyalogoshíd eltérő magassága, a közös HÉV és a buszmegálló kerítéses szétválasztása az egy ember szélességü bejárattal) a mérnöki szakma szégyene, amit tetéz a háromféle megoldású esőbeálló telepítése. Elfogadhatatlan, hogy a MÁV-HÉV és a MÁV-START megállóiban nincs a másikra vonatkozó tájékoztatás, és a megközelítési lehetőségek rajza is hiányzik.

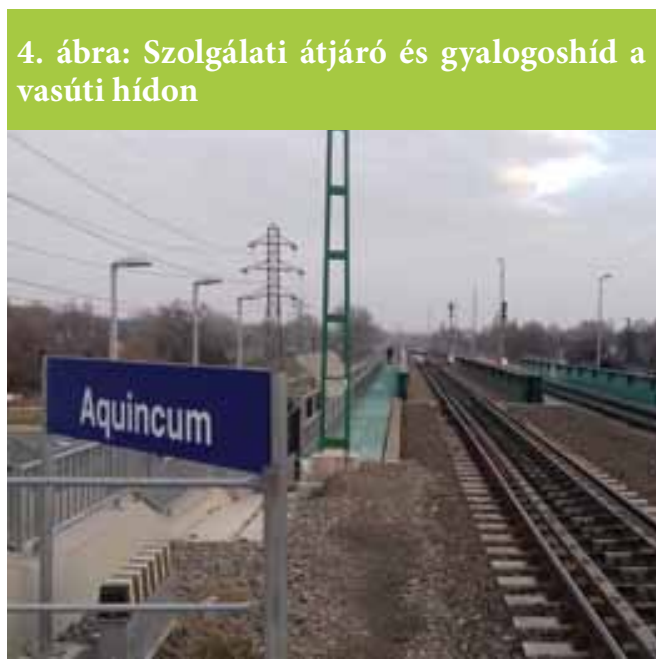




\section{Vasúti közlekedés}

$\mathrm{Az}$ esztergomi beruházás megkezdése előtt ígért menetidő-csökkenést jelenleg a csak hétköznap közlekedő zónázó vonatok utasai élvezhetik. A vonal villamosításának késedelme és a Desiro motorvonatok romló üzemkészsége miatt nincs elegendő korszerü vonatszerelvény. A felújított vonalon ezért újra megjelentek a mozdony vontatta Bhv ingaszerelvények. A csúcsidei vonatokon nőtt a zsúfoltság, az utasok elégedetlenkednek. A rosszabb gyorsulású dízel szerelvényekre nem lehet a kiépült vonal adottságait figyelembe vevő optimális menetrendet elkészíteni; emiatt sok helyen a vonalra engedélyezett sebesség sem használható ki.

\begin{tabular}{|c|c|c|c|c|c|}
\hline & $\begin{array}{l}\text { vonat- } \\
\text { nem }\end{array}$ & $\mathrm{km}$ & $\begin{array}{c}\text { me- } \\
\text { netidő } \\
2010\end{array}$ & $\begin{array}{c}\text { me- } \\
\text { netidő } \\
2017\end{array}$ & $\begin{array}{l}\text { elté- } \\
\text { rés } \\
\text { perc }\end{array}$ \\
\hline $\begin{array}{c}\text { Budapest-Nyugati- } \\
\text { Esztergom }\end{array}$ & személy & 53 & 87 & 84 & 3 \\
\hline $\begin{array}{l}\text { Budapest-Nyugati- } \\
\text { Esztergom }\end{array}$ & zónázó & 53 & - & 67 & -20 \\
\hline $\begin{array}{c}\text { Budapest-Nyugati- } \\
\text { Piliscsaba }\end{array}$ & személy & 32 & 54 & 54 & 0 \\
\hline $\begin{array}{c}\text { Budapest-Nyugati- } \\
\text { Piliscsaba }\end{array}$ & zónázó & 32 & - & 42 & -12 \\
\hline
\end{tabular}

Az eredmény felemás. A zónázó vonatok menetideje jelentősen csökkent, a személyvonatoké változatlan maradt.

\subsection{Girbe-gurbán az Alföld közepén: Szolnok-Szajol-Püspökladány}

A $160 \mathrm{~km} / \mathrm{h}$ sebességre alkalmas vasúti pályát 2015. november 5-én avatták fel, ennek ellenére még mindig nem mehetnek a vonatok ezzel a sebességgel. Ehhez a megfelelö kocsi, mozdony és vonatbefolyásoló berendezés hiányzik. A vonatok gyakorlatilag a felújítás előtti menetrenddel és szerelvényekkel járnak. Ez nagyon nagy luxus több mint 155 milliárd forintért.

Öt állomáson peronaluljárók épültek, a vonal mentén közúti alul- és felüljárók készültek. A pályafelújításba nem fért bele a felvételi épületek korszerüsítése, ezért a MÁV saját forrásból újítja fel Kisújszállási, Karcag és Püspök- ladány állomásépületét. Sajnos az átépített vonal állomásain az épületekből kilépve kerítésbe ütközik az utas, és csak az aluljárón keresztülhaladva lehet vonatra szállni, holott az első vágány az előtetős épület előtt van. A 400 méter hosszú peronokra telepített új perontetők gyakorlatilag csak a függöleges, csendes esőtől védenek. Az Alföld közepén minden állomáson girbe-gurba az átvezetés, sőt van ahol ívesített kitérő is épült.

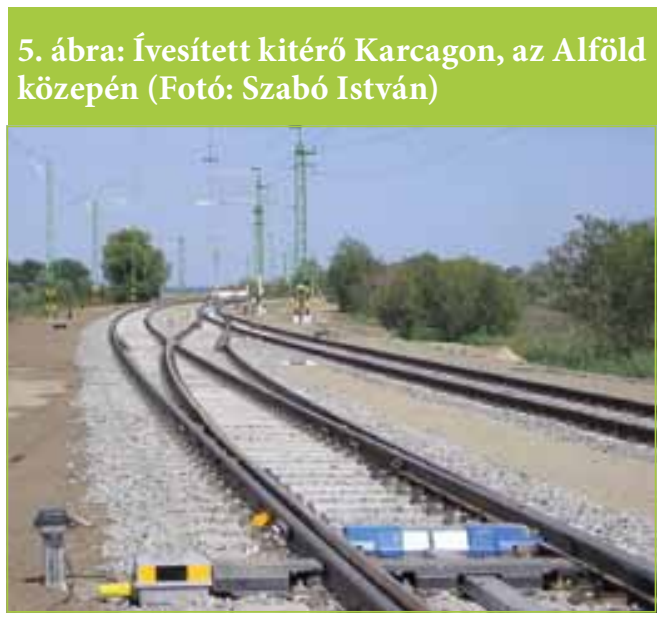

Hiányoznak a peronokról a szélfogók. Esetlegesek a megközelítési útvonalak, figyelmen kívül hagyták az utasáramlást, sok a kivitelezési hiba. Megépültek és zömében müködnek is a liftek. Ugyanakkor semmibe vezetö, csatlakozó út nélküli liftes kijáratok épültek Karcagon és Kisújszálláson az Ipartelep irányába. A kerékpártároló igényt rosszul határozták meg, a megépített tárolókapacitás elégtelen vagy rossz helyre telepítették.

A külső szemlélő számára feltűnő a vasúti pálya melletti vízelvezető árkok hiánya vagy több spontán vízelvezető megléte és a sok álló víz a pályatest mellett.

A vonalszakasz az előzetes ütemezés szerint, a határidőket betartva épült. Az utazóközönség viszonylagos türelemmel viselte a megpróbáltatásokat, amelyek során az IC és a gyorsvonat rendre egyesítve, természetesen lényegesen hosszabb menetidővel közlekedett, így lehetővé téve az egyik vágány forgalomból történő kizárását. Gondot jelentett a kör IC vonatok közle- 
kedtetésének szünetelése is. Az építés tervezett határidejét a Fegyvernek-Örményes közelében a vasúti pályába a korábbi felújítás során beépített világháborús löszeres vonat feltárása, valamint a püspökladányi müemlék fütőház áttelepítését és újjáépítését lehetővé tevő szakszerü bontása miatti időkiesés sem befolyásolta.

A Nemzeti Közlekedési Hatóság a vonalat még nem helyezte üzembe. Az ETCS rendszerű vonatbefolyásolás hiányában az átépített szakaszokon is maradt a 120 kilométer/ óra maximális sebesség, és az eljutási idő sem változott Szolnok - Püspökladány között.

\begin{tabular}{|c|c|c|c|c|c|}
\hline & $\begin{array}{c}\text { vonat- } \\
\text { nem }\end{array}$ & $\mathrm{km}$ & $\begin{array}{c}\text { me- } \\
\text { netidő } \\
2010\end{array}$ & $\begin{array}{c}\text { menet- } \\
\text { idő } \\
2017\end{array}$ & $\begin{array}{l}\text { eltérés } \\
\text { perc }\end{array}$ \\
\hline $\begin{array}{c}\text { Szolnok- } \\
\text { Püspökladány }\end{array}$ & IC & 77 & 45 & 42 & -3 \\
\hline $\begin{array}{c}\text { Szolnok- } \\
\text { Püspökladány }\end{array}$ & sebes & 77 & 62 & 62 & 0 \\
\hline $\begin{array}{l}\text { Szolnok- } \\
\text { Debrecen }\end{array}$ & IC & 121 & 74 & 74 & 0 \\
\hline $\begin{array}{l}\text { Szolnok- } \\
\text { Debrecen }\end{array}$ & sebes & 121 & 101 & 99 & -2 \\
\hline
\end{tabular}

A debreceni vonatok menetidő-csökkenését a Tisza-híd átépítése és sebességemelése eredményezte nem a pályarekonstrukció.

\subsection{Luca széke, avagy vasútépítés-tech- nikai bemutató kísérlet: Budapest-Szé- kesfehérvár}

A 2008-ban kezdett felújítás keretében 2013-ra teljesen megújult a vasúti pálya. Nagytétény és Velence, valamint Agárd és Székesfehérvár között 160, a Velencei-tó partján Velence és Agárd között $120 \mathrm{~km} / \mathrm{h}$ lesz a megengedett pályasebesség, ha az ETCS rendszer kiépül. Kelenföld és Tárnok között megépült a hiányzó második vágány, így Kelenföldtől Székesfehérvárig kétvágányú pályán vonatozhatunk.

Nagytétény személyforgalma megszünt, helyette Kastélypark megállóhelyen állnak meg a vonatok. Dinnyés állomás helyett a település mellett épült új megállóhely, Érd alsó és Albertfalva állomásból megállóhely lett. A hosszú építési idő nagyon megnehezítette az itt utazók életét. Az egyvágányú szakaszokon lebonyolódó helyi és távolsági közlekedés, a folyamatosan változó menetrendek, a kábelvágások, biztosítóberendezési zavarok miatti rendszeres késések sok gondot okoztak. Az utasok reménytelenségét fokozta, hogy a $\mathrm{Bu}$ dapesthez közelebbi szakasz a beruházás utolsó ütemében épült meg, így a már elkészült vonalszakaszok előnyeit nem nagyon élvezhették. A vonal egyes állomásközeit különböző kivitelezők különböző építési technológiával építették meg. Az igazi szenzáció a TárnokMartonvásár szakasz nagygépes átépítése volt.

Eltúlzott méretű, kihasználhatatlan új épület épült Kápolnásnyék és Tárnok állomáson. A megemelt utasperon miatt a velencei-tavi megállóhelyek állomásépületeit lebontották és újraépítették.

A vonal elkészülte után az utasok megpróbáltatásai nem értek véget, mert Székesfehérvár átépítése újabb kényelmetlenséget okozott, és a távolban ott van még a pusztaszabolcsi vonal átépítése, amikor Budafok vágányait és felsővezetékét áthelyezve a középperont ki kell szélesíteni, hogy megfeleljen az elöírásoknak. És nem beszéltünk még a tervezett és személyszállítási szempontból nagyon fontosnak tünő Nagytétény-Érd összekötő vágány megépítésének zavarhatásáról.

A vonal elektronikus biztosítóberendezése nehezen állt be a sorba. Jelenleg is rendszeresen rakoncátlankodnak a jelzők vagy a sorompók. Különösen nehezen dolgozott együtt a Siemens biztosítóberendezés a Siemens Desiro motorvonatokkal, így ezeket - egy időre számüzték is a vonal nyári forgalmából.

Annak ellenére, hogy az engedélyezett pályasebesség még csak $120 \mathrm{~km} / \mathrm{h}$, ezen a vonalon a menetidő egyértelmü rövidüléséről és az új motorvonatok közlekedtetésével, az új vonatok beállításával és a KőbányaKispestre átemelő viszonylat bevezetésével a szolgáltatási színvonal növekedéséről, a martonvásári központú új forgalomirányítás bevezetésével pedig a menetrendszerüség javulásáról beszélhetünk. Itt az utasok türelme 


\section{Vasúti közlekedés}

nem volt hiábavaló. Ellentétben a püspökladányi vonallal, amely az átépítés előtt is 120 $\mathrm{km} / \mathrm{h}$ sebességgel volt járható - itt az átépítést megelőzően a pálya tele volt $20-40 \mathrm{~km} / \mathrm{h}$ lassújelekkel és a $20 \mathrm{~km}$ egyvágányú szakasz sem segítette a gyors eljutást.

\begin{tabular}{|c|c|c|c|c|c|}
\hline & $\begin{array}{l}\text { vonat- } \\
\text { nem }\end{array}$ & $\mathrm{km}$ & $\begin{array}{c}\text { me- } \\
\text { netidö } \\
2010\end{array}$ & $\begin{array}{c}\text { menet- } \\
\text { idö } \\
2017\end{array}$ & $\begin{array}{l}\text { elté- } \\
\text { rés } \\
\text { perc }\end{array}$ \\
\hline $\begin{array}{l}\text { Budapest-Déli- } \\
\text { Székesfehérvár }\end{array}$ & személy & 67 & 84 & 64 & -20 \\
\hline $\begin{array}{l}\text { Budapest-Déli- } \\
\text { Székesfehérvár }\end{array}$ & zónázó & 67 & - & 59 & -25 \\
\hline $\begin{array}{l}\text { Budapest-Déli- } \\
\text { Székesfehérvár }\end{array}$ & gyors & 67 & 66 & 47 & -19 \\
\hline
\end{tabular}

\section{A FONTOSABB ÁLLOMÁSFEJLESZ-}

\section{TÉSEK}

\subsection{A kályha: Vác}

A váci vasútállomás teljes körü átépítése 2013 augusztusában kezdődött. A munkák során teljesen megújult a váci állomás, átépült a vasúti pálya és a vágányhálózat, négy új, tetövel, lifttel ellátott magasperon épült.

Az átépítés szűnni nem akaró panaszáradattal indult, mivel az egyvágányú közlekedés menetrendi problémák sorát hozta magával. A veresegyházi vonatok Vác-Alsóvárosig, a balassagyarmati vonatok Kisvácig közlekedtetése és a közbeeső szakasz vonatpótló buszozása sok utas életét keserítette meg. A menetrend rendszeresen összeomlott biztosítóberendezési hiba, felsővezeték-szakadás vagy a mozdonyok szolgálatképtelensége miatt.

A nem reprezentatív felmérésem azt jelzi, hogy az utasok szerint a vasút nem kellő hatékonysággal védte utasai érdekeit a kivitelező kényelmes munkavégzésével szemben. A kezdeti nehézségek után lassan konszolidálódott a helyzet és elkészült az állomás.

A váci állomás kialakítása és üzemeltetése az utas szemével több hiányosságot tartalmaz. Hiába épült meg az állomás közepén a kettős vágánykapcsolat, a peron közepe nem használható.
A tervező szerint a szabályok nem teszik lehetővé az sk $+55 \mathrm{~cm}$-s peron ilyen megépítését, a laikus külső szemlélő szerint viszont olyan keskenyre sikerült a föperon, hogy a lépcsőfeljáró két oldalán nem lehetett az elö́rt peronszélességet biztosítani, ezért kellett a peron közepét lezárni.

A meglévő vágánykapcsolatokat nem használják, így az átszálló utasoknak rendre aluljárózniuk kell.

A felvételi épület előtt formás kerítés épült. Itt sincs peron, tehát felszállási lehetőség az előtetőnél. A végpont felőli aluljáróból nem lehet feljönni a felvételi épülethez. Egy lépcső és $50 \mathrm{~m}$ járda hiányzik. Ugyanebből az aluljáróból csak 360 fokos keringővel lehet a két föperonra jutni. A peronon elhelyezett tájékoztató táblák nem láthatók az aluljáróból, csak a lépcső közepétől. A liftek ajtaja a peronon a vágányra merőleges, balesetveszélyes. Nincs szélfogó, esőbeálló a peronokon. Elmulasztották a felsővezetéket kiépíteni Kisvác megállóhelyig, ezért az ide utazó diákoknak át kell szállniuk a mellékvonali szerelvénybe.

A felvételi épület példás műemléki helyreállítása Bánszky Szabolcs tervezőt dicséri.

A váci pénztárcsarnok kicsi, de a céloknak megfelel, még egy kis üzletet is beszuszakoltak az utastérbe. A Kormányablak beköltöztetése újabb funkciót adott az állomásépületnek.

A vasúti szakemberek váci tapasztalataik alapján a következő nagy átépítéseknél, Székesfehérvárnál és Békéscsabánál már sok hibalehetőséget ki tudtak védeni.

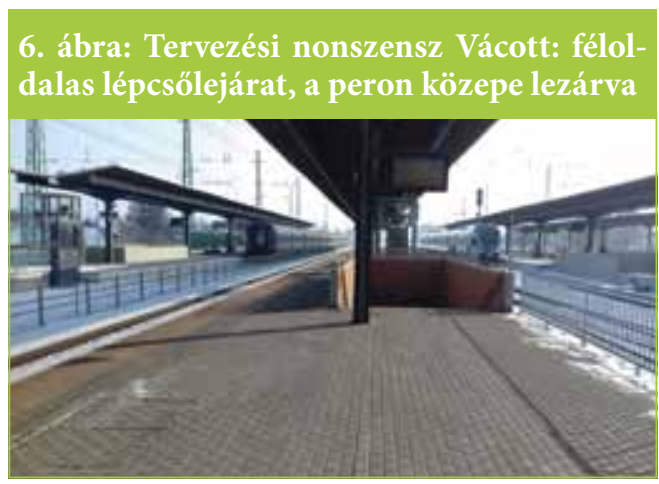




\section{Vasúti közlekedés}

\section{2.Összehangolva: Békéscsaba}

Békéscsaba állomás átépítése 2013-2016 között zajlott. Új vágányhálózat létesült magasperonokkal. Itt sikerült osztott vágányú peronokat építeni és végre van funkciója az első vágánynak, sajnálatos, hogy csak sk+33 $\mathrm{cm}$-s peronnal. Nehezen magyarázható, hogy a két azonos funkciójú középperon szélessége miért eltérő. Egy vagy két tehervonati vágány feladásával célszerü peronok épülhettek volna.

Megújult a régi és az új felvételi épület, aluljáró épült a buszpályaudvarig, Az állomás elötti tér is új arculatot kapott. Igényes kialakítású az ügyfélközpont. Ötletes az aluljáró épület alatti részének lezárása a peronok és a buszpályaudvar felőli oldalon. Ezzel huzatmentessé és zárhatóvá vált a csarnok.

A épületek mủemléki felújítása igényes, európai színvonalú. Bánszky Szabolcs és B. Terbe Erzsébet volt a tervező.

Természetesen az átadás után sincs még minden készen. Valamennyi elárusító hely gazda nélküli. Így a fó csarnok mindkét oldalán, a Kormányablak folyosóján és az aradi végen is üresen állnak a kereskedelmi helyiségek. Zavaró, hogy a WCblokk közvetlenül a pénztárak végéhez került és bejárata uralja a keresztfolyosót.

A melléképületek felújítása nem történt meg. Jó lenne, ha a hulló vakolatú épületek is kisebb felújítást kaphatnának.

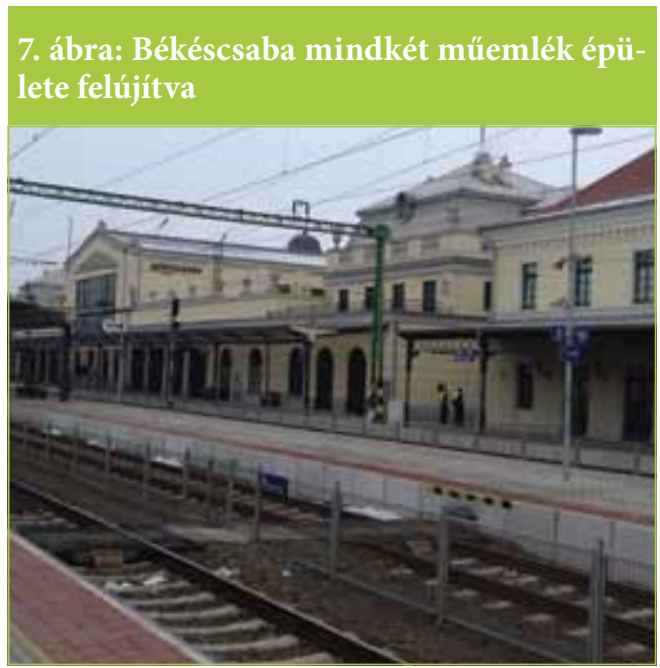

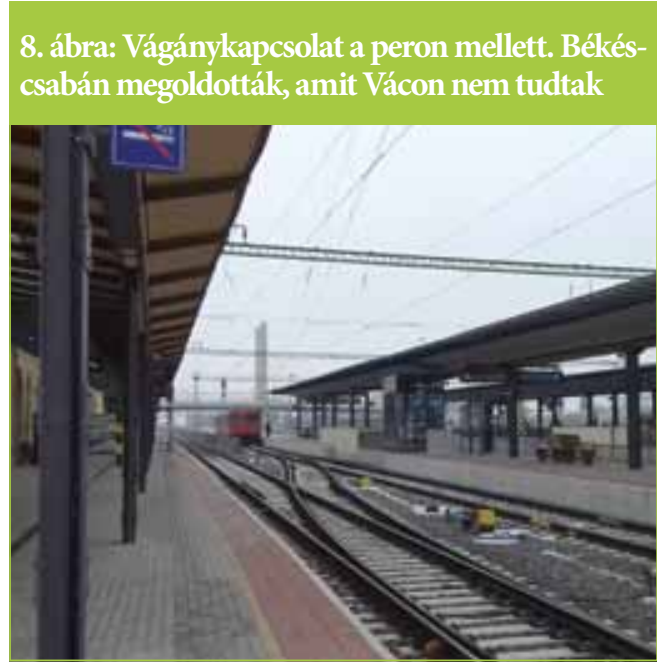

5.3. Majdnem jól szervezve: Székesfehérvár

Székesfehérvár átépítésének megszervezése már a váci tapasztalatok figyelembevételével történt. Az állomás átépítése alatt a vonatforgalmat négy vágány felhasználásával bonyolították le. A helyi vonatok többségének fordítása pedig Gárdonyban, Lepsényben vagy Szabadbattyánban történt. Sokat segített az állomási technológia kialakításán a kisebb forgalmú vonalak forgalmának autóbuszra terelése. Amitől mindenki félt, a világháborús bombák megtalálása, igazából nem okozott problémát. Az átépítés ideje alatt az állomás a nyári balatoni forgalmat is nagyobb zavar nélkül lebonyolította.

Az új vágányhálózat, a korszerü utaskiszolgáló létesítmények és az utastájékoztató berendezések megfelelnek a kor követelményeinek. Természetesen ez a beruházás sincs egészen kész, mert még nincs üzemben a felüljáró és a Kormányablak is épül. Bízzunk abban, hogy a most felúiításra nem kerülő épületrészek legalább friss vakolatot és festést kapnak.

Kár, hogy a pénztárpultok átalakítása nem történt meg. Utasként nem szerencsés látni, mit rakosgat a pénztáros a terem túlsó oldalán a páncélszekrényébe.

A szokásos takarékosságnak eshetett áldozatul a lépcsőfeljáró pesti oldaláról hiányzó szélfogó és információs fal. Kár, hogy a ter- 


\section{Vasúti közlekedés}

vezőkben nem tudatosult még, hogy a lépcsöfeljárókat öbölszerüen célszerü kialakítani, hogy a közlekedők ne döntsék fel egymást.

Az érkező és induló utasforgalom keveredik. A korábbi érkezési csarnok funkció nélkülivé vált, mivel megközelítése az aluljáró felől csak az első vágány peronján át lehetséges.

A figyelmes szemlélö itt is rengeteg kivitelezési hiányosságot találhat (fugahiány, egyenetlen padozat, csorba csempe vagy padlólap). Jó lenne, ha a finanszírozó ezeket garanciálisan kijavíttatná. Természetesen a peronok itt is tele vannak kábelaknákkal és szakszerűtlenül készült földelési vezetékekkel. Jó lenne, ha a MÁV egységes elveket találna ki ezek kialakítására és rendbetételére.

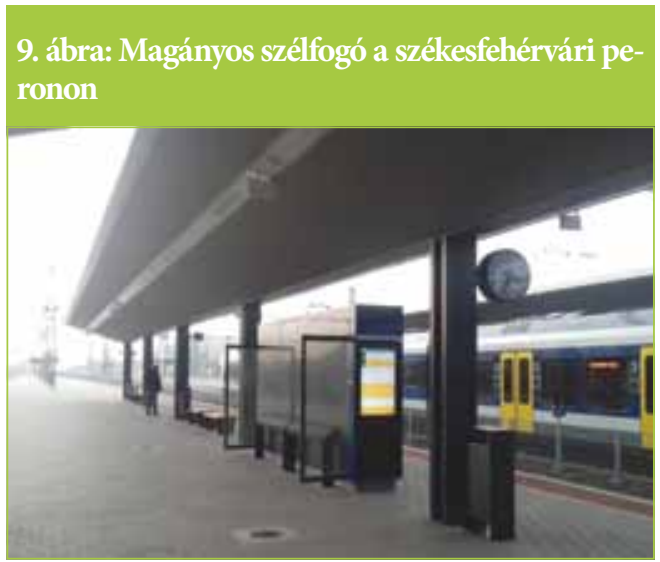

\section{A KÖZELMÚLT FONTOSABB ÉPÜ- LETKORSZERÚSÍTÉSEI}

A magyar vasútállomások általános képe siralmas. A legrosszabb helyzetben a nagy utasforgalmú állomások vannak. Ezek többségére a lepusztultság, a felelős gazda hiánya jellemző. Az elmúlt időszakok fejlesztései általában újabb épületekkel bővítették az állomásokat, a meglévőket sorsukra hagyva, és csak ritkán került sor a funkciót vesztett létesítmények eltüntetésére. A MÁV épületképének jellemzője a törött, piszkos vagy éppen bedeszkázott ablak, a hulló vakolat, az egyenetlen peron és járda, a sáros állomási előtér, a gaz és a mindent elborító graffiti.
Az ilyen alapkép mellett különösen örömteli az olyan kezdeményezésekről és megvalósult fejlesztésekről beszámolni, amelyek megpróbálják javítani a helyzetet, élhetővé tenni az állomásokat és megóvni az építészeti értékeket az utókor számára.

\subsection{Kituintetve: a nagykátai vonal állo- másépuiletei}

2011 és 2015 között a MÁV saját forrásai felhasználásával korszerüsítette a nagykátai vonal műemlék jellegü állomásépületeit, új megállóhelyi típusépületeket és megállóhelyi esőbeállókat épített. Tíz helyszínen - Maglód, Sülysáp, Szőlősnyaraló, Tápiószecső, Nagykáta, Farmos, Tápiószele, Tápiógyörgye és Újszász - a meglévő épületeket újították fel, de Mende csak 2016-ban készült el. Maglódi nyaralón és Szentmártonkátán a régi épületek helyett újat emeltek, Rákoshegyen és Ecseren a meglévő épületet korszerüsítették. Rákoskert, Pusztaszentistván, Tápiószentmárton és Zagyvarékas megállóhelyen modern formájú esőbeállókat alakítottak ki. A felújítások a korszerü mosdók, várótermek, jegypénztárak kialakítását is tartalmazták, biztosítva az akadálymentes használatot is. Az épületekben kereskedelmi létesítmények elhelyezésére is gondoltak. Az egységes építészeti koncepció megtervezése a Hajnal Építész Iroda Kft. és a MÂV Zrt. építészcsapata érdeme. Az egy év alatt megvalósításra tervezett projekt végül hat évet igényelt, de megérte.

A nagykátai vonal épületeinek felújításáért a MÁV Zrt. a 2014. évi Brunel-díj - „a vasútépítészet Oscar-díja" - után 2016. évben a hazai Icomos-dijat is átvehette.

Jó lenne hasonló koncepció alapján a folytatást látni a többi budapesti elővárosi vonalon vagy a Balaton parti vasútvonalakon.

Az épületek jelenleg is szépek, az utasterek és a WC-blokkok müködnek.

Van ahol az állomás környéke is megszépült, bár a vandálok több helyen megjelentek. Az utóbbi időben a vandál támadások elsősorban a jegykiadó automaták ellen irányul- 


\section{Vasúti közlekedés}
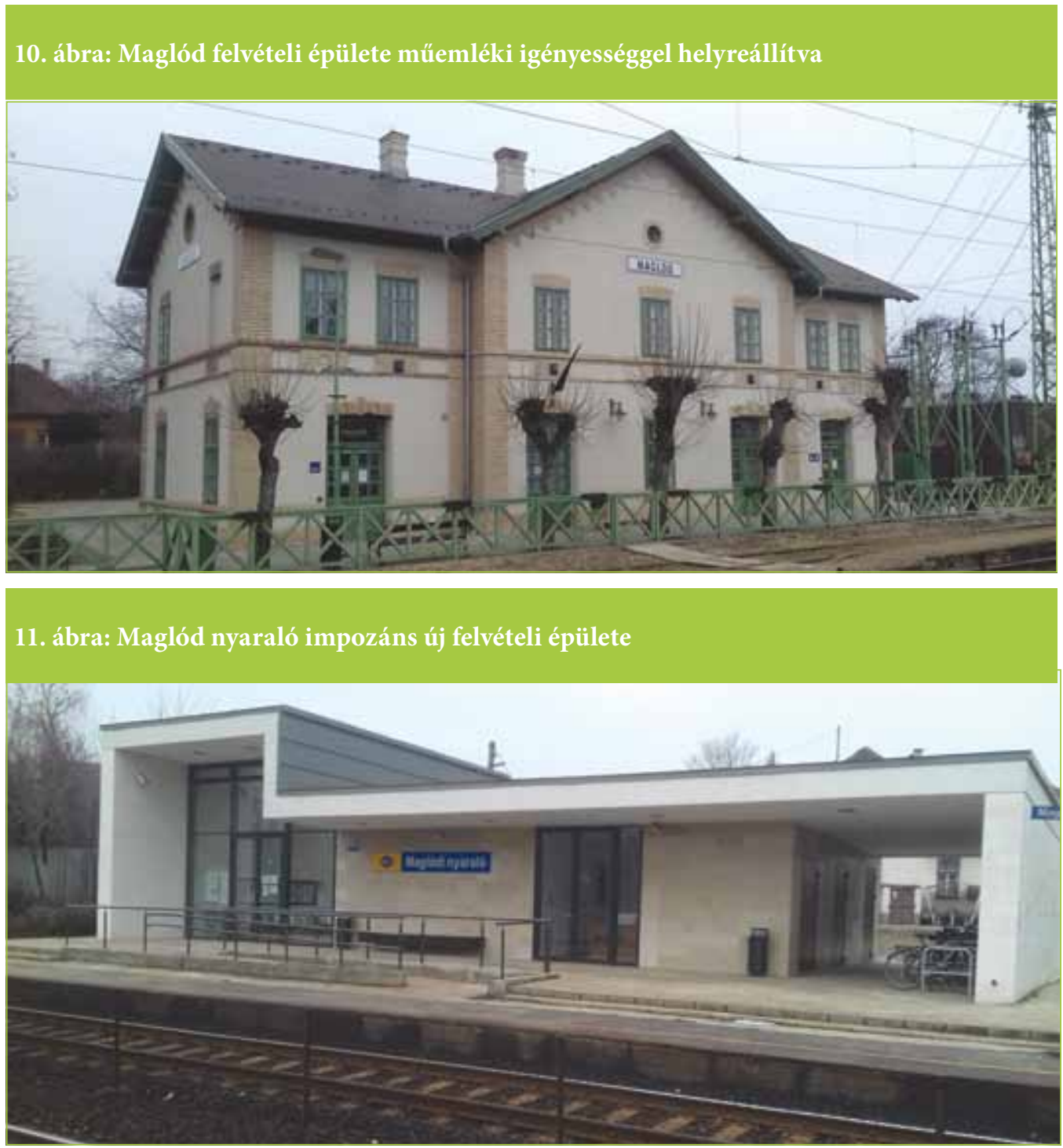

nak (például Pusztaszentistvánon). Sajnos a kereskedelmi terek bérbeadása nem történt meg. Maglód, Sülysáp város felőli, kereskedelmi célra szánt helyiségeiben a vasút lomokat tárol, Maglód nyaralón is zárva az üzlethelyiség. Máshol is így lehet. Kár érte.

\subsection{A háttérben csendesen: a Sáránd-} Nagykereki vonal állomásfejlesztései

A Debrecen-Nagykereki vasútvonalon és keresztirányú autóbusz-hálózatán új, akadálymentesített peronok, átszállási pontok, busz- fordulók, parkolók és megállók épültek „Az értől az óceánig” projekt keretében. A projekt központja a Pocsaj-Esztár vasútállomáson elkészült „Érmelléki decentrum”, ahol az akadálymentesített vasúti peronok mellett egy autóbusz-forduló és két autóbuszállás épült. Különlegesség, hogy közös vasúti és autóbusz peron épült, így a csúcsforgalmi irányban utazók a közös peronon szállhatnak át. Nagykereki állomáson szintén közös állomást alakítottak ki, amelynek köszönhetően a jövőben autóbusszal lehet majd továbbutazni Biharkeresztesre. 


\section{Vasúti közlekedés}

12. ábra: Pocsaj-Esztár intermodális utasperonja (Fotó: Szabó István)

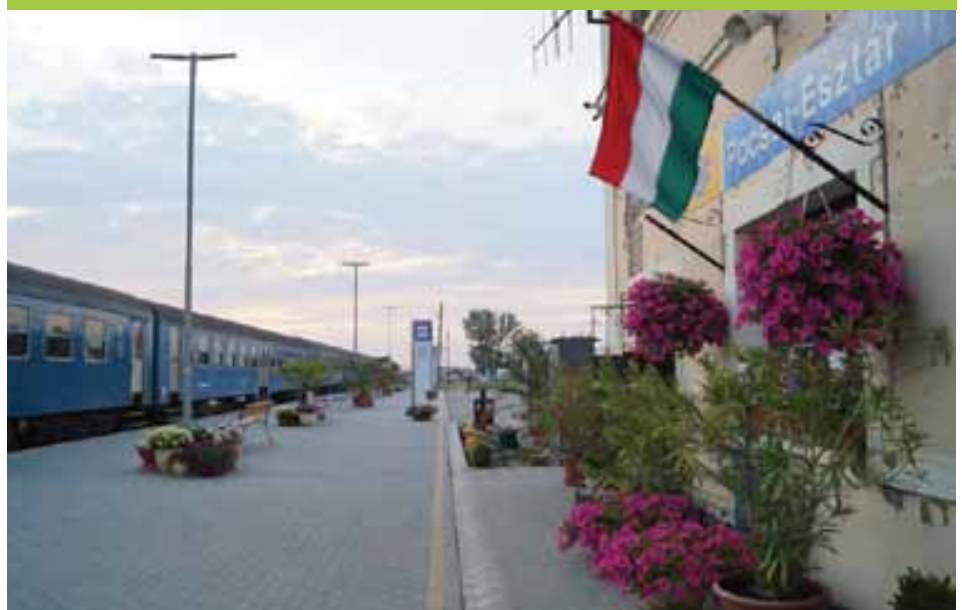

sítmények üzemeltetése, karbantartása is. Külön alapos vizsgálatot érdemelne, hogy az állomásokon korábban kiépített, majd a felújítások során is megtartott kereskedelmi és vendéglátó létesítmények miért kihasználatlanok. A MÁV miért nem talál üzemeltetőt számukra. Felülvizsgálandó az ilyen létesítmények szükségessége, hasznossága a gyakoribb, ütemes személyszállítási szolgáltatás tükrében és megvizsgálandó, hogy milyen szolgáltatásokra, milyen

Civil kezdeményezésre jobb menetrendet készítettek a vonalra. A reggeli csúcsidei követés jelenleg negyven perc. Sárándon, Derecskén, Derecske-Vásártéren, Konyári Sóstófürdőn, Kismarján a a normál vágánytengely-távolságba szabálytalan, de az utasok számára kényelmes sk+30 cm-s peronok épültek.

Konyár állomáson utólag épül új peron, de itt a MÁV éber volt, ezért ez az elöírásoknak megfelelő $\mathrm{sk}+15 \mathrm{~cm}$-s lesz.

\section{7.ÖSSZEFOGLALÁS}

Az elmúlt időszak vasútfejlesztései az utas szemével nem támasztják alá a politikusi és vasúti vezetői hurráoptimizmust. Annak ellenére, hogy néhány kiemelkedő színvonalú épület megújult, a vonalfejlesztések vontatottan haladtak A fejlesztések eredménye nem vagy csak részben mutatkozik meg a szolgáltatási színvonal növekedésében, az eljutási idő rövidülésében és a menetrendszerüség javulásában.

Az elhúzódó építési munkák és a több ütemre széthúzott (pálya, biztosítóberendezés, forgalomirányítás, ETCS, GSMR) beruházások csak lassan hoznak eredményt. A pályaépítéssel biztosított sebességemelés elmarad az egyes beruházási elemek kihagyása, illetve az eszközfejlesztés késedelmei miatt.

Gondot jelent a megépült kereskedelmi léte- bérleti konstrukciókra lenne szükség.

A vasút rendszer minden elemét (szolgáltatás, pálya, jármü, ingatlan) figyelembe vevő, átgondolt, hosszú távra előre megalapozott és előre, megfelelöen ütemezett, a teljes keresztmetszet egyenkapacitását biztosító, az elöírásoknak megfelelően üzemeltethető fejlesztésekre van szükség. Minden érdekelt döntéshozó, tervező, kivitelező, üzemeltető és nem utolsó sorban oktatási szakember feladatául kell adni a fejlesztési tapasztalatok elemzését: mindenki a saját szakterületén vizsgálja meg, hogy mi az oka a projektek elhúzódásának, drágulásának, a müszaki tartalom hiányosságainak, a szakmailag kifogásolható megrendelői, tervezői, kivitelezői munkának. Az érintetteknek meg kell tenniük a szükséges intézkedéseket annak érdekében, hogy az európai és a hazai beruházási és fenntartási pénzek felhasználása a lehető leggyorsabban, a legtöbb hasznot hozva történjen meg.

Iránymutatóként legyen a zárszó a MÁV 1916ban készített beruházási javaslatának bevezetéseként megfogalmazott gondolat [10].

"Hogy a végrehajtandó beruházások átgondolt, egységes terv szerint végeztessenek és így az ötletszerü intézkedések hátrányai mellőztessenek, szükséges több évre terjedőleg elöre megállapítani a beruházási szükségleteket és azok okszerü egymásutánban történő végrehajtásának sorrendjét. 
Behatóan foglalkoztunk tehát azzal a kérdéssel, hogy melyek lesznek azok a beruházások, melyek hasznosságuk és sürgősségük sorrendjében első sorban lennének végrehajthatók és amelyek a leggyorsabban teremnék meg a befektetés gyümölcsét, úgy az általános gazdasági élet, mint a vasút pénzügyi igazgatása nézőpontjából is."

(A cikk a szerzőnek a VII. Közlekedéstudományi Konferencián (Györ, 2017. március 30-31.) elhangzott és a konferencia kiadványában megjelentetett elöadásának továbbfejlesztése [1])

[Az „átlagos utas”, de azért ennél több, talán „szakértö utas" tapasztalataira, javaslataira jó lenne, ha a munkákban résztvevők (tervezök, kivitelezök, beruházók) reflektálnának, mert így Olvasóinkban is tisztulhatna a kép. (A szerkesztöség)]

\section{FELHASZNÁLT IRODALOM}

[1] Perger Imre:Az elmúlt évek vasúti fejlesztései egy utas szemével Közlekedéstudományi Konferencia, Győr 2017. március 31.
[2] Dr. Kormányos László-Perger Imre-Földiák János A budapesti körvasút bevonási lehetősége a vasúti személyszállításba Közlekedéstudományi Szemle:2016. 3. szám 21-34.

[3] MÁV és Volán forgalomszámlálás Budapesten belül Budapesti Müszaki és gazdaságtudományi Egyetem Közlekedésmérnöki Kar Közlekedésüzemi Tanszék 2010.

[4] Magyar Államvasutak statisztikai zsebkönyve 1974 MÁV Budapest, 1975.

[5] Magyar Államvasutak statisztikai zsebkönyve 1980 MÁV Budapest, 1981.

[6] Magyar Vasúttörténet 6. 1945-től 1972-ig MÁV Budapest, 1998

[7] Magyar Vasúttörténet 7. 1973-tól 1998-ig MÂV Budapest, 1999

[8] Közforgalmú Menetrend 2009-2010.

[9] Közforgalmú Menetrend 2016-2017.

[10] Javaslat a Magyar Királyi Államvasutak hálózatán a háború lezajlását követő legközelebbi években szükséges beruházásokról és a hálózat továbbfejlesztéséről Budapest, 1916.

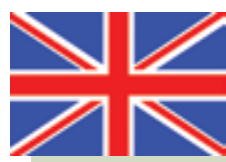

\section{Railway developments, from a passengers point of view}

During the period 2007-2013, significant rail improvements were carried out with the help of EU funding. Despite the obvious results, it was observed that these developments were generally not coordinated sufficiently. Because of the delay in the completion of train control systems or the lack of suitable vehicles, the speed of the newly built railway tracks cannot be used sufficiently, so there has been no decrease in travel time. The length of lines renewed using EU sources is not sufficient for the planned upgrading of the network. This would require additional domestic resources. It is unfavourable that in the 1970s, the volume of the modernization of railway tracks, the electrification of railway lines and vehicle purchase was significantly larger than today. The historical station reconstruction, and the operation, preservation and commercial utilization of historical railway facilities is not yet resolved.

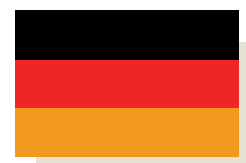

\section{Bahnentwicklungen aus Sicht der Fahrgäste}

Im Zeitraum von 2007-2013 wurden mit Hilfe der EU-Mittel erhebliche Bahnmodernisierungen durchgeführt. Es kann trotz der offensichtlichen Ergebnisse festgestellt werden, dass diese Entwicklungen im Allgemeinen nicht ausreichend koordiniert wurden. Wegen der Verzögerung bei der Fertigstellung von Zugsteuerungssystemen bzw. wegen dem Mangel an geeigneten Fahrzeugen kann die Geschwindigkeit der neu gebauten Eisenbahnschienen nicht ausreichend genutzt werden, so dass es keine Verkürzung der Fahrzeit gab. Die Länge der Linien, die mit EU-Quellen erneuert werden, reicht für die geplante Modernisierung des Netzes nicht aus. Dies würde zusätzliche nationale Ressourcen erfordern. Es ist ungünstig, dass in den siebziger Jahren das Volumen der Modernisierung der Eisenbahnschienen, der Elektrifizierung von Eisenbahnlinien und der Beschaffung von Schienenfahrzeugen deutlich größer war als heute. Die Rekonstruktion von historische Stationen sowie ihre Operation, Erhaltung und kommerzielle Nutzung ist noch nicht gelöst. 